\title{
Articulation and speaking rates of Polish-French bilingual children
}

\begin{abstract}
BACKGROUND
Bilingualism or multilingualism, while being of great benefit, often presents a significant challenge for experts. In fact, the linguistic development process for monolingual and bilingual speakers differs significantly. Even though such milestones as a baby's first words or sentences are often reached at the same time in both cases, other phenomena typical for bilingualism may appear to be disorders or delays if considered within the categories of monolingualism. The objective of the present study was to determine whether there were differences between the achievements of monolingual and bilingual children in the field of some prosodic speech aspects.
\end{abstract}

PARTICIPANTS AND PROCEDURE

The objective of the study was to collate research results concerning the speaking rates of bilingual speakers, and to compare them to the established standards in the field. The research material was obtained from a group of $16 \mathrm{bi}-$ lingual children, unaffected by developmental, language or communication disorders, which was then described and analysed in terms of established research criteria, and compared to analogical data derived from a control group consisting of 16 monolingual children. The average age of the bilingual children was $8 ; 11$ and of the monolingual children from the control group 9;0.

\section{RESULTS}

The analysis of the material collected leads to the conclusions that, in terms of the basic parameters determining the speaking rates of the speech produced, statistically significant differences occurred between the monolingual and bilingual groups in the categories of average speaking rate (speech sounds and syllables per second, and pause duration) and the average articulation rate (speech sounds, syllables). There were no significant differences regarding number of pauses or the average duration of filled pauses.

\section{CONCLUSIONS}

The quantitative results and their statistical analysis agree with the hypothesis regarding slower speech production by bilingual children.

\section{KEY WORDS}

bilingualism; pauses; speaking rate; articulation rate

ORGANISATION - 1: Department of Neurolinguistics, Pedagogical University of Cracow, Poland - 2: Department of

Logopaedics, University of Gdansk, Poland · 3: Institute of Philology, Pedagogical University of Cracow, Poland .

4: European School Brussels I, Belgium

AUthors' Contributions - A: Study design - B: Data collection - C: Statistical analysis - D: Data interpretation .

E: Manuscript preparation · F: Literature search · G: Funds collection

CORRESPONDING AUTHOR - Prof. Ewa Czaplewska, Department of Logopaedics, University of Gdansk,

58 Wita Stwosza Str., 80-309 Gdańsk, Poland, e-mail: logec@ug.edu.pl

to Cite this ARTiCle - Michalik, M., Czaplewska, E., Solak, A., \& Szkotak, A. (2018). Articulation and speaking rates

of Polish-French bilingual children. Health Psychology Report, 6(4), 330-338. https://doi.org/10.5114/hpr.2018.76180

RECEIVED 26.03.2018 · REVIEWED · 22.05.2018 · ACCEPTED 02.06.2018 · PUBLISHED 26.07.2018 


\section{BACKGROUND}

In the contemporary world, most people are either passive or active users of more than one language (Grosjean, 1982, 2010; Tucker, 1998). In some countries where more than one official language may exist, as in Belgium, with French, Flemish and German, multilingualism becomes the norm. Due to the increasing rate of economic, social, and political migration, more than two languages are often used within a single country or region (Langdon \& Saenz, 2016). Bilingualism or multilingualism, while undoubtedly of great benefit, often presents a significant challenge for experts, including psychologists and speech and language therapists, whose professional tasks include the need to determine the development of a bilingual speaker, and, if necessary, to design appropriate therapy. The severe lack of diagnostic tools for multilingual speakers (Haman, Łuniewska, Mayniak, \& Wodniecka, 2018; Kohnert, 2013; McLeod \& Verdon, 2014), as well as deep-rooted, often scientifically unsupported superstitions regarding atypical language development in bilingual individuals, often result in actions that could hardly be described as 'supportive'. For example, most students in Dutch schools for children with special educational needs (including language disorders) are bilingual (de Jong, Çavuş, \& Baker, 2010). In the UK, bilingual children are less often referred to a specialist to determine the risk of language development disorders, due to the popular belief that the language learning period in the case of bilingual children is naturally protracted (Cattani et al., 2014).

In fact, the linguistic development process for monolingual and bilingual speakers differs significantly (Genesee \& Nicoladis, 2007; Grosjean, 1982, 2010). Even though milestones such as a baby's first words or sentences are often reached at the same time (Werker, Byers-Heinlein, \& Fennell, 2009), other phenomena typical for bilingualism may be viewed as disorders or delays if considered solely within the parameters of monolingualism. Such phenomena can include negative phonological (e.g. Chang, 2016; Marecka, Wrembel, Zembrzuski, \& OtwinowskaKasztelanic, 2015) or syntactic (e.g. Dussias \& Sagarra, 2007) transfer between two languages. Negative transfer, also referred to as language interference, is the result of a switch in language structures between languages which do not share such structures or in which the structure serves a different function (Wodniecka, Mieszkowska, Durlik, \& Haman, 2018). Grammatical transfer occurs most frequently when one of the child's languages is dominant (Paradis \& Genesee, 1996) and in such a situation, lexical transfer, the appropriation of words from one language into the other, may also occur, most often when a child cannot find an appropriate word in one language, usually the weaker of the two (Clark, 2009).
Such phenomena may be categorised as the 'price' of bilingualism, and their intensity predominantly depends on the type of bilingualism in question.

Therefore, given the time criterion in which the two systems are acquired, bilingualism may be divided into simultaneous and sequential. In terms of the effect obtained, it may be further sub-divided into balanced and imbalanced (Wodniecka et al., 2018). Simultaneous bilingualism refers to children who have been acquiring both languages since birth (De Houver, 2009), while sequential bilingualism occurs when a person first acquires one language (L1) and then, having reached a certain level of proficiency, begins to learn the other (L2). Balanced bilingualism is observed when a person is capable of using both languages with a similar ease and degree of fluency (Zurer-Pearson, 2013).

In practice, however, individuals who have perfectly mastered two or more languages are very rarely encountered. In light of this premise, researchers more and more frequently assume that bilingual individuals may be defined as those who use more than one language on an everyday basis and who may speak the other language less fluently or with a pronounced accent (Grosjean \& Ping Li, 2012; ArmonLotem, de Jong, \& Meir, 2015). Such a broader definition of bilingualism embraces a group of bilingual individuals which may comprise children with different family situations and life histories. It may also include children who have been raised since birth in a country other than that of their parents, or children one of whose parents speaks a majority language and the other a language of their country of origin, etc. Varied intensity of contact with both languages is the basic and the most important factor affecting the functioning of bilingual speakers (De Houwer, 2011; Zurer-Pearson, 2013). For this reason, proficiency in both languages does not necessarily develop evenly. The lexicon and variety of grammatical forms depend on language input as well as the intensity of practice in either of the languages.

However, regardless of the type of bilingualism, for people who daily use more than one language both languages are active to a certain degree and compete over which is to be used in any given moment (Kroll, Bobb, \& Wodniecka, 2006; Kroll, Bobb, \& Hoshino, 2014). The phenomenon of coactivation occurs inadvertently in both adults and children (von Holzen \& Mani, 2012), regardless of the type of bilingualism or even linguistic modality (if we take account of individuals who use sign language, see Morford, Wilkinson, Villwock, Piñar, \& Kroll, 2011). This coactivation of languages may explain the prolonged language processing time in bilingual speakers (Gollan, Montoya, Fennema-Notestine, \& Morris, 2005; Gollan, Montoya, \& Werner, 2002; Starreveld, de Groot, Rossmark, \& van Hell, 2014), a phenomenon which is in turn directly linked to the time
Articulation and speaking rates of bilingual children 
Mirosław Michalik, Ewa Czaplewska, Anna Solak, Anna Szkotak required for the selection of words from the mental lexicon, i.e. to the so-called lexical access, which is slower in bilingual than monolingual speakers (Ivanova \& Costa, 2008). The slowing down of this process has a direct influence on the speed with which an utterance is formed.

Increased difficulty in accessing one's own lexical resources may also result in various kinds of disfluency in the speech of bilingual individuals (Howell, Davis, \& Williams, 2009; Byrd, Bedore, \& Ramos, 2015), one consequence of which may be a slower pace of utterance when compared to monolingual speakers.

\section{DETERMINING THE PARAMETERS FOR SPEECH PRODUCTION SPEED: ARTICULATION AND SPEAKING RATES}

The phenomena of speech production speed can be described by two notions - the articulation rate and the speaking rate. The former is defined as a category describing the number of sounds/syllables produced within a particular phrase within a given period of time. Removing the duration of pauses is the first step in calculating the articulation rate. The speaking rate entails complementing data with the formal characteristics of the pauses (such as duration and fulfilment level) which occur between the phrases (rhythm groups), but which at the same time contribute to a particular utterance, along with its sounds and syllables (Lovit, 2014; Wagner, 2017). Within the process of determining the articulation rate, the analysis included repeatedly occurring rhythm groups (phrases), each lasting approximately 2-3 seconds (Woźniak, 2012; Michalik \& Solak, 2017), while phrases, as defined by Agnieszka Wagner (2017, p. 16), are "the rhythm units constituting a perceptually whole form (Gestalt)". Crucial in determining the articulation rate are the pauses which occur between phrases - defined as breaks in the phonic sequence, a zero sound under the acoustic sign system, and empty segments on a sound wave (Polański, 1999). Although irrelevant in determining the articulation rate, breaks, including units within phrases (speech sounds and syllables) and pauses, are important in the analysis of speaking rate, and are determined on the basis of utterances comprising more than one phrase (Michalik \& Solak, 2017).

Pauses influence the speaking rate, and can be divided into three categories based on variations in the form that the utterance takes - silent pauses, partly filled pauses, and filled pauses (Śniatkowski, 2002). A silent (unfilled) pause is a moment of silence, a break in the speaking process that occurs between utterance units, for example, during inspiration or expiration. A filled pause is a break in the speaking process, taking one of three forms (Śniatkowski, 2002): a lexical unit (usually repetition of a particular element of the utterance or as a unit realising its phatic function), as in the sentence 'I was in a bookstore'; a verbal sound (such as a drawled vowel or vowel group), which may be heard as 'yyy', 'eheh' and may imply that the speaker is unsure of what to say next; or finally a non-verbal extra-linguistic sound such as a cough. A partly filled pause, as defined by Sławomir Śniatkowski, is a combination of a silent pause and a filled pause (2002), an example being: 'I was in a [ahah-] bookstore', where '-' denotes silence.

The objective of the present study was to determine whether differences exist between the achievements of monolingual and bilingual children in the field of prosodic speech aspects such as speaking rate, articulation rate, and the number and duration of silent, filled and partly filled pauses. The main hypothesis was that the utterances of speakers from the two groups should indeed differ in all of these categories.

\section{PARTICIPANTS AND PROCEDURE}

\section{PARTICIPANTS}

The research material, obtained from a group of 16 bilingual children with no previous documented history of developmental, language or communication disorders, was described and analysed according to the established research criteria set out above, and then compared to the analogical data from a control group consisting of 16 monolingual children. The average subject age was $8 ; 11$ years in the bilingual group and 9;0 years in the monolingual group, with a gender ratio of $5(\mathrm{~F})$ to $11(\mathrm{M})$. It was assumed that monolingual children of this age have already achieved linguistic competency. The control group consisted of monolingual Polish students from a primary school in Tarnów, while the test group consisted of students from the Polish section of European School of Brussels I, who use Polish at school on weekdays between 8.00 a.m. and 4.00 p.m. and French and Polish at home ${ }^{1}$. On the assumption that simultaneous bilingualism appears on condition that L2 is introduced before the age of three, the test group could be considered simultaneous bilingual children, having been born in Belgium to mixed Polish-French-speaking families, in line with the 'one person one language' strategy (OPOL). All children participating in the study had attended exclusively French-language kindergartens until the age of 6 .

Given the fact that the children live in francophone Brussels but also learn through the medium of Polish and have at least one Polish parent, it may be assumed that Polish is spoken at least as often as French, i.e. at least $50 \%$ of the time. 


\section{METHOD AND PROCEDURE}

The objective of the study was to collate the research results concerning the speaking rates of bilingual speakers, and compare these to the established standards in this field (Solak, 2018). The first stage entailed collecting audio recordings of the utterances of both monolingual and bilingual children. Each child was already familiar with the researcher through a student-teacher relationship, and during individual sessions the following questions were asked: What do you do in your class/group/school? How do you like to play? What do you do at your after-school club? What have you done today? What did you do yesterday? What do you usually do at home? And What are you going to do? In all cases, parental consent was given prior to the study.

A continuous, uninterrupted, 30-second speech utterance was chosen from the recording. If the extract contained more than one utterance of similar length which met the criteria, only the first was chosen.

The initial stage of the analysis involved listening to the full recording. A simple transcription was made by repeatedly listening to the utterances, which then enabled the number of speech sounds and pauses to be determined. The transcription met the formal criteria of orthography (the script includes grammatical errors in speech). The transcription was complemented by the addition of information about the duration and form of the pauses that occurred during the utterance. Audacity (2014) software was used to obtain this information. Because the aim of the analysis was to detect silent, partly filled, and filled pauses, which often take the form of repetitions, use of the software's automated pause detection and measurement function was not possible, as this type of software does not detect pauses which take the form of phonic units.

After determining the number of speech sounds and syllables, the articulation rate could be calculated. Further analyses focused on the quantitative and qualitative characteristics of the pauses, which allowed the speaking rate and pause time percentage to be determined.

\section{RESULTS}

In order to answer questions regarding potential differences in the speed of the speech production process, a comparative quantitative analysis was conducted regarding the parameters shown in Tables 1 and 2, which are in turn related to the duration of speech, the articulation rate and the presence of certain types of pauses in the utterances of the children under study.

Statistical analyses of the material collected, conducted using the Shapiro-Wilk test in order to estab- lish whether a sample comes from a normal distribution, the Mann-Whitney test to assess whether the medians of a given phenomenon differ between the two groups, and parametric tests, produced the required indicator parameters. The results are presented in Tables 1 and 2.

The analysis of the material collected and the adoption of a significance level of $p<.001$ led to the identification of statistically significant differences between the mono- and bilingual students participating in the study with regard to the average speaking rate (speech sounds/s, syllables/s, and pause duration) and the average articulation rate (speech sounds/s, syllables/s, and pause duration). The monolingual students achieved higher results in both categories.

The adoption of a significance level of $p<.05$ resulted in the identification of statistically significant differences between the two groups of mono- and bilingual students, with regard to the average pause occurrence utterances (in percent). Significant differences were determined for the detailed secondary parameters - average total pause duration (s), average silent pause duration (s), and average partly filled pause duration (s). The monolingual students achieved lower results.

There were no significant differences regarding the pause number and the average filled pause duration.

\section{DISCUSSION}

The quantitative results and the statistical analysis agree with the hypothesis regarding slower speech production by bilingual students. Even though they met the definition of simultaneous and balanced bilingualism, their articulation and speaking rates were indeed lower than their monolingual peers. According to the standards established for the Polish language, the average articulation rate is 10-15 speech sounds/s (Milewski, 2017; Woźniak, 2012). Here the average articulation rate was 11.23 speech sounds/s for monolingual speakers (Michalik \& Solak, 2017), as compared to 9.28 speech sounds/s for the bilingual speakers, i.e. less than the accepted lower limit. Significant differences were found for type and frequency of pauses, which together constitute the category of speaking rate and the speed of articulatory movement. Their general share in the utterances, particularly the frequency and duration of the silent and partly filled pauses, clearly indicated that the language performance of monolingual and bilingual students differed significantly in terms of speaking rate.

Due to the fact that only differences between the average pause duration were determined, and not their number (except for filled pauses), it can
Articulation and speaking rates of bilingual children 
Table 1

Differences between students' results in terms of speaking rate and speed of speech production (speech sounds/ syllables per second)

Mirosław Michalik, Ewa Czaplewska, Anna Solak, Anna Szkotak

\begin{tabular}{|c|c|c|c|c|c|c|c|c|c|c|c|}
\hline \multirow{3}{*}{$\begin{array}{l}\text { Parameters } \\
\text { tested }\end{array}$} & \multicolumn{10}{|c|}{ Group } & \multirow{3}{*}{$\begin{array}{l}\text { Test } \\
\text { result }\end{array}$} \\
\hline & \multicolumn{5}{|c|}{ Monolingual } & \multicolumn{5}{|c|}{ Bilingual } & \\
\hline & $M$ & $S D$ & $\min$ & $\max$ & $M e$ & $M$ & $S D$ & $\min$ & $\max$ & Me & \\
\hline $\begin{array}{l}\text { Duration of } \\
\text { speech }\end{array}$ & 19.23 & 1.95 & 15.73 & 22.59 & 19.10 & 14.71 & 4.21 & 6.60 & 21.84 & 15.08 & $\begin{array}{c}t=3.90 \\
d f=21 \\
p<.001\end{array}$ \\
\hline $\begin{array}{l}\text { Average articula- } \\
\text { tion rate: speech } \\
\text { sounds per } \\
\text { second }\end{array}$ & 11.23 & 1.50 & 8.69 & 13.72 & 11.52 & 9.28 & 1.48 & 6.95 & 11.78 & 9.82 & $\begin{array}{l}t=3.70 \\
d f=30 \\
p<.001\end{array}$ \\
\hline $\begin{array}{l}\text { Average articula- } \\
\text { tion rate: syl- } \\
\text { lables per second }\end{array}$ & 4.67 & 0.62 & 3.53 & 5.71 & 4.70 & 3.84 & 0.50 & 2.90 & 4.50 & 4.02 & $\begin{array}{c}t=4.13 \\
d f=30 \\
p<.001\end{array}$ \\
\hline $\begin{array}{l}\text { Average speak- } \\
\text { ing rate: speech } \\
\text { sounds per } \\
\text { second }\end{array}$ & 7.19 & 1.27 & 5.70 & 10.33 & 7.12 & 4.61 & 1.66 & 1.63 & 7.23 & 4.40 & $\begin{array}{c}t=4.94 \\
d f=30 \\
p<.001\end{array}$ \\
\hline $\begin{array}{l}\text { Average speaking } \\
\text { rate: syllables per } \\
\text { second }\end{array}$ & 2.99 & 0.53 & 2.20 & 4.30 & 2.97 & 1.90 & 0.65 & 0.70 & 3.03 & 1.80 & $\begin{array}{l}t=5.17 \\
d f=30 \\
p<.001\end{array}$ \\
\hline
\end{tabular}

Table 2

Differences between students' results in terms of pauses in utterances

\begin{tabular}{|c|c|c|c|c|c|c|c|c|c|c|c|}
\hline \multirow{3}{*}{$\begin{array}{l}\text { Parameters } \\
\text { tested }\end{array}$} & \multicolumn{10}{|c|}{ Group } & \multirow{3}{*}{$\begin{array}{l}\text { Test } \\
\text { result }\end{array}$} \\
\hline & \multicolumn{5}{|c|}{ Monolingual } & \multicolumn{5}{|c|}{ Bilingual } & \\
\hline & $M$ & $S D$ & $\min$ & $\max$ & $M e$ & $M$ & $S D$ & $\min$ & $\max$ & Me & \\
\hline $\begin{array}{l}\text { Silent pauses: } \\
\text { average duration }\end{array}$ & 4.32 & 2.26 & 0.62 & 8.13 & 4.56 & 7.33 & 3.90 & 1.83 & 14.78 & 6.88 & $\begin{array}{c}t=-2.67 \\
d f=30 \\
p=.012\end{array}$ \\
\hline $\begin{array}{l}\text { Filled pauses: } \\
\text { average duration }\end{array}$ & 1.38 & 1.40 & 0.00 & 3.82 & 0.80 & 0.53 & 0.71 & 0.00 & 2.36 & 0.00 & $\begin{aligned} U & =80.00 \\
p & =.063\end{aligned}$ \\
\hline $\begin{array}{l}\text { Partly filled } \\
\text { pauses: average } \\
\text { duration }\end{array}$ & 5.07 & 2.27 & 0.00 & 7.91 & 5.67 & 7.43 & 3.28 & 2.16 & 13.80 & 8.13 & $\begin{array}{c}U=67.00 \\
p=.022\end{array}$ \\
\hline Pause duration & 10.77 & 1.95 & 7.41 & 14.27 & 10.90 & 15.29 & 4.21 & 8.16 & 23.40 & 14.93 & $\begin{array}{c}t=-3.90 \\
d f=21 \\
p<.001\end{array}$ \\
\hline Pause number & 12.56 & 2.76 & 7.00 & 18.00 & 12.00 & 11.69 & 2.89 & 5.00 & 16.00 & 12.00 & $\begin{array}{c}t=0.88 \\
d f=30 \\
p=.388\end{array}$ \\
\hline $\begin{array}{l}\text { Pause time } \\
\text { percentage in } \\
\text { the utterances }\end{array}$ & 35.90 & 6.50 & 24.70 & 47.56 & 36.33 & 50.98 & 14.04 & 27.20 & 78.00 & 49.75 & $\begin{array}{c}t=-3.90 \\
d f=21 \\
p<.001\end{array}$ \\
\hline
\end{tabular}


be assumed that the pauses in the utterances of the monolingual and bilingual speakers occurred at similar stages of the speech production process, which was probably a result of their having learnt the prosodic language features. On the other hand, the prolonged pause duration in the utterances of the bilingual speakers might reflect the protracted language processing time. Some pauses were filled with physiological phenomena such as coughs or yawns, which naturally also occurred in the utterances of the monolingual speakers. The silent and partly filled pauses for the bilingual speakers included periods of silent time, which either served a semantic function or marked more intense information processing (Levelt, 1989; Schmidt, 1992), such as searching for suitable expressions or grammatical forms. The same phenomenon has been described for adult speakers who stopped using L1 after moving to another country, which impaired access time to their mental lexicon or activation of the correct grammatical form (Bergmann, Sprenger, \& Schmid, 2015). The fact that speakers who stop using L1 on a daily basis are much less fluent than typical monolingual speakers proves that language fluency level does not depend solely on knowledge of the language, but rather on the possibility of using it in everyday life. Therefore, the fact that the bilingual children under study spoke Polish more slowly than their monolingual counterparts may be attributed to their more intermittent use of this language.

Less frequent contact with each of the languages may explain the greater difficulty in accessing the personal mental lexicon, as demonstrated by bilingual individuals' slower rate when naming pictures (Bialystok, Craik, \& Luk, 2008; Ivanova \& Costa, 2008). The lower speaking rate determined in the present study concurs with the results of Gollan and Kroll's study (2001), which proved that bilingual speakers have lower competencies in lexical processing tasks. This can probably be attributed to the fact that bilingual speakers need more time than their monolingual peers to complete these types of task. Studies by Bialystok et al. (2008), and Ivanova and Costa (2008), have also demonstrated that bilingual speakers name pictures at a slower rate, which may indicate greater difficulty in accessing the personal mental lexicon.

This study proves the validity of the hypothesis that obstructed access to the mental lexicon is measurable not only during laboratory tests concerning lexical resources, but also in normal bilingual speakers.

It is suggested that the lower speaking rates for bilingual speakers may derive from the coactivation of two languages rather than any lack of language competence (Bergmann et al., 2015), and that parallel processing of languages may lead to a delay in speech processing (Hartsuiker \& Notebaert, 2010).
The general consensus for bilingual speakers is that both languages are constantly active (Bialystok et al., 2008), which creates the potential for continual competition, even when a conversation takes place in only one language. Such a phenomenon might have been at play in the bilingual children who participated in the present study.

A lower speaking rate for bilingual children may in addition be connected with working memory capacity. The source literature discusses close relations between high speaking rate and singular working memory (Cowan et al., 1998). Although most studies confirming the relationship between working memory capacity and speaking rate discuss cases involving 5- and 6-year-olds (Gathercole \& Adams, 1994; Jarrold, Hewes, \& Baddeley, 2000), Cohen and Heath's study (1990) confirmed this relationship for 10- and 11-year-olds.

It is suggested that the lower operational level of the phonological loop for bilingual children is the result of constant shifting between languages (Bialystok, Luk, Peets, \& Yang, 2010; Ivanova \& Costa, 2008). As is known (Baddeley \& Hitch, 1974), the phonological loop involves the repetition of words, with the system being burdened by the additional process of language coactivation. On the other hand, this shifting between languages, the need to constantly monitor and to divide attention, may also increase the functioning of the working memory (Bialystok \& Craik, 2010; Kroll, Dussias, Bogulski, \& Valdes Kroff, 2012). In this case, it may not be the attention but the alternatives from the two language forms which simultaneously occur within the phonological loop structure that, as a consequence, determine how long the process of planning an utterance lasts. In the opinion of Jarrold et al. (2000), pause duration in spontaneous utterances is indeed related to individual differences in speech planning processes. Therefore, during the significantly longer pauses in the bilingual children under study, as opposed to monolingual children, utterance planning processes might have been taking place based on the two coexisting language forms.

The study presented focused on bilingual children with supposedly well-grounded Polish in terms of everyday and school vocabulary. Their speaking rates, and therefore their speech processing rates, were significantly lower than those of the Polish monolingual speakers. These data may, for example, have a strong practical impact on cognitive competence diagnostics regarding those children. It is worth remembering that even sound knowledge of a language does not guarantee that a bilingual speaker will achieve the same times for processing information tasks as a monolingual speaker. For this reason, applying the same time limits employed for monolingual speakers may lead to a false diagnosis. The diagnosis of bilingual individuals should be
Articulation and speaking rates of bilingual children 
based on tools standardised on the same population and with consideration for the specific nature of speech processing in bilingual speakers.

\section{CONCLUSION AND LIMITATIONS OF THE STUDY}

The study results indicated a slower speech rate in bilingual children when contrasted with their monolingual peers. Although this result may have a practical application, some limitations should nevertheless be considered. Most importantly, it should be remembered that, although the bilingual children participating in the study functioned in a dual Polish-French environment, individual differences may have existed in relation to their competence in Polish. It would therefore be valuable in the future to undertake a further study on speech rate as dependant on level of language proficiency. Another issue worth considering is whether similar results would have been obtained by comparing Polish monolingual children with bilingual counterparts who use a language other than French. What remains unclear in the case of Polish and French is whether we are witnessing some form of language interference as regards speech rate. We could therefore benefit from future research which extends to other language pairs as well as to a larger sample population.

\section{ENDNOTES}

1 European Schools have operated since 1953, when the European Coal and Steel Community was established, thereby laying the foundations for today's European Union. All EU countries can establish their own language section, so that the children of employers of EU institutions can study in their native language, which facilitates the process of returning to their native country after their parents' tenure or contract terminates. While living in a multicultural and international environment, students have the right to study in their native language with respect for their own traditions, allowing them to build a sense of community with other European citizens, while at the same time teaching them acceptance and respect for their own identity and cultural uniqueness. The European School learning program is an outcome of cooperation between a number of ministries of national education.

\section{RefERENCES}

Armon-Lotem, S., de Jong, J., \& Meir, N. (2015). Methods for assessing multilingual children: disen- tangling bilingualism from Language Impairment. Bristol: Multilingual Matters.

Audacity Team. (2014). Audacity(R): Free Audio Editor and Recorder [Computer program]. Version 2.1.0 retrieved September $19^{\text {th }} 2015$ from http:// audacity.sourceforge.net/

Baddeley, A., \& Hitch, G. (1974). Working memory. In G. A. Bower (ed.), The Psychology of learning and motivation: Advances in research and theory (pp. 47-89). New York: Academic Press.

Bergmann, C., Sprenger, S. A., \& Schmid, M. S. (2015). The impact of language co-activation on L1 and L2 speech fluency. Acta Psychologica, 161, 25-35.

Bialystok, E., \& Craik, F. I. (2010). Cognitive and linguistic processing in the bilingual mind. Current Directions in Psychological Science, 19, 19-23.

Bialystok, E., Craik, F. I., \& Luk, G. (2008). Cognitive control and lexical access in younger and older bilinguals. Journal of Experimental Psychology: Learning, Memory, and Cognition, 34, 859-873.

Bialystok, E., Luk, G., Peets, K. F., \& Yang, S. (2010). Receptive vocabulary differences in monolingual and bilingual children. Bilingualism: Language and Cognition, 13, 525-531.

Byrd, C. T., Bedore, L. M., \& Ramos, D. (2015). The disfluent speech of bilingual Spanish-English children: Considerations for differential diagnosis of stuttering. Language, Speech, and Hearing Services in Schools, 46, 30-43. http://doi.org/10.1044/2014_ LSHSS-14-0010

Cattani, A., Abbot-Smith, K., Farag, R., Krott, A., Arreckx, F., Dennis, I., \& Floccia, C. (2014). How much exposure to English is necessary for a bilingual toddler to perform like a monolingual peer in language tests? International Journal of Language and Communication Disorders, 49, 649-671. https://doi.org/10.1111/1460-6984.12082

Chang, C. B. (2016). Bilingual perceptual benefits of experience with a heritage language. Bilingualism: Language and Cognition, 19, 791-809. https://doi. org/10.1017/S1366728914000261

Clark, E. V. (2009). First language acquisition. Cambridge: Cambridge University Press.

Cohen, R. L., \& Heath, M. (1990). The development of serial short-term memory and the articulatory loop hypothesis. Intelligence, 14, 151-171.

Cowan, N., Wood, N. L., Wood, P. K., Keller, T. A., Nugent, L. D., \& Keller, C. V. (1998). Two separate verbal processing rates contributing to short-term memory span. Journal of Experimental Psychology: General, 127, 141-160.

De Houver, A. (2009). Bilingual first language acquisition. Bristol-Buffalo, NY: Multilingual Matters.

De Houwer, A. (2011). Language input environments and language development in bilingual acquisition. Applied Linguistics Review, 2, 221-240.

De Jong, J., Çavuş, N., \& Baker, A. (2010). Language impairment in Turkish-Dutch bilingual children. 
In S. Topbaş \& M. Yavaş (eds.), Communication disorders in Turkish (pp. 288-300). Bristol: Multilingual Matters.

Dussias, P. E., \& Sagarra, N. (2007). The effect of exposure on syntactic parsing in Spanish-English bilinguals. Bilingualism: Language and Cognition, 10, 101. https://doi.org/10.1017/S1366728906002847

Gathercole, S. E., \& Adams, A. (1994). Children's phonological working memory: Contributions of long-term knowledge and rehearsal. Journal of Memory and Language, 33, 672-688.

Genesee, F., \& Nicoladis, E. (2006). Bilingual acquisition. In E. Hoff \& M. Shatz (eds.), Handbook of language development (pp. 324-342). Oxford: Blackwell.

Gollan, T. H., \& Kroll, J. F. (2001). Bilingual lexical access. In B. Rapp (ed.), The handbook of cognitive neuropsychology: What deficits reveal about the human mind (pp. 321-345). New York: Psychology Press.

Gollan, T. H., Montoya, R. I., Fennema-Notestine, C., \& Morris, S. K. (2005). Bilingualism affects picture naming but not picture classification. Memory \& Cognition, 33, 1220-1234. https://doi. org/10.3758/BF03193224

Gollan, T. H., Montoya, R. I., \& Werner, G. A. (2002). Semantic and letter fluency in Spanish-English bilinguals. Neuropsychology, 16, 562-576. https:// doi.org/10.1037/0894-4105.16.4.562

Grosjean, F. (1982). Life with two languages. Cambridge, MA: Harvard University Press.

Grosjean, F. (2010). Bilingual: Life and reality. Cambridge, MA: Harvard University Press.

Grosjean, F., \& Ping Li (2012). The psycholinguistics of bilingualism. Oxford: John Wiley \& Sons.

Haman, E., Łuniewska, M., Maryniak, A., \& Wodniecka, Z. (2018). Specyficzne zaburzenie językowe (SLI) i dwujęzyczność: pozorne związki i realne konsekwencje z perspektywy psychologicznej [Specific language impairment (SLI) and bilingualism: false relationships and real consequences from the psychological perspective]. In E. Czaplewska (ed.), Logopedia międzykulturowa [Intercultural logopaedics] (pp. 150-175). Gdańsk: Harmonia-Universalis.

Hartsuiker, R. J., \& Notebaert, L. (2010). Lexical access problems lead to disfluencies in speech. Experimental Psychology, 57, 169-177. http://dx.doi. org/10.1027/1618-3169/a000021

Howell, P., Davis, S., \& Williams, R. (2009). The effects of bilingualism on speakers who stutter during late childhood. Archives of Disease in Childhood, 94, 42-46.

Ivanova, I., \& Costa, A. (2008). Does bilingualism hamper lexical access in speech production? Acta Psychologica, 127, 277-288. https://doi. org/10.1016/j.actpsy.2007.06.003

Jarrold, C., Hewes, A. K., \& Baddeley, A. D. (2000). Do two separate speech measures constrain verbal short-term memory in children? Journal of Experimental Psychology: Learning, Memory, and Cognition, 26, 1626-1637.
Kohnert, K. (2013). Language disorder in bilingual children and adults ( $2^{\text {nd }}$ ed.). San Diego, CA: Plural Publishing.

Kroll, J. F., Bobb, S. C., \& Hoshino, N. (2014). Two languages in mind: Bilingualism as a tool to investigate language, cognition, and the brain. Current Directions in Psychological Science, 23, 159-163. https://doi.org/10.1177/0963721414528511

Kroll, J. F., Bobb, S. C., \& Wodniecka, Z. (2006). Language selectivity is the exception, not the rule: Arguments against a fixed locus of language selection in bilingual speech. Bilingualism, 9, 119-135. https://doi.org/10.1017/ S1366728906002483

Kroll, J. F., Dussias, P. E., Bogulski, C. A., \& Valdes Kroff, J. R. (2012). Juggling two languages in one mind: What bilinguals tell us about language processing and its consequences for cognition. In B. H. Ross (ed.), Psychology of learning and motivation advances in research and theory (vol. 56, pp. 229-262). San Diego: Elsevier.

Langdon, H. W., \& Saenz, T. I. (2016). Working with interpreters and translators: A guide for speechlanguage pathologists and audiologists. San Diego, CA: Plural Publishing, Inc.

Levelt, W. J. M. (1989). Speaking: From intention to articulation. Cambridge, MA: MIT Press.

Lovit, A. (2014). Acquired motor speech disorders. In L. Cummings (ed.), The Cambridge handbook of communication disorders (pp. 400-418). Cambridge: Cambridge University Press.

Marecka, M., Wrembel, M., Zembrzuski, D., \& Otwinowska-Kasztelanic, A. (2015). Do early bilinguals speak differently than their monolingual peers? Predictors of phonological performance of Polish-English bilingual children. Proceedings of the International Symposium on Monolingual and Bilingual Speech.

McLeod, S., \&Verdon, S. (2014). A review of 30 speech assessments in 19 languages other than English. American Journal of Speech-Language Pathology, 23, 708723. https://doi.org/10.1044/2014_AJSLP-13-0066

Michalik, M., \& Solak, A. (2017). The pace of speech in autistic spectrum disorder (ASD). Acta Neuropsychologica, 15, 433-441.

Milewski, S. (2017) Tempo mówienia [The speaking rate]. http://www.encyklopedialogopedii.pl/tikiindex.php?page=TEMPO+M\%C3\%93WIENIA. Retrieved on: 21.11.2017.

Morford, J. P., Wilkinson, E., Villwock, A., Piñar, P., \& Kroll, J. F. (2011). When deaf signers read English: Do written words activate their sign translations? Cognition, 118, 286-292. https://doi. org/10.1016/j.cognition.2010.11.006

Paradis, J., \& Genesee, F. (1996). Syntactic acquisition in bilingual children: autonomous or independent? Studies in Second Language Acquisition, 18, 1-25. https://doi.org/10.1017/S0272263100014662
Articulation and speaking rates of bilingual children 
Mirosław Michalik, Ewa Czaplewska, Anna Solak, Anna Szkotak
Polański, K. (ed.). (1999). Encyklopedia językoznawstwa ogólnego [The encyclopaedia of linguistics]. Wrocław-Warszawa-Kraków: Ossolineum.

Schmidt, R. (1992). Psychological mechanisms underlying second language fluency. Studies in Second Language Acquisition, 14, 357-385.

Solak, A. (2018). The speaking rate of children's speech utterances. Unpublished dissertation. Kraków: Neurolinguistics Department of Polish Philology of the Pedagogical University in Kraków.

Starreveld, P. A., de Groot, A. M. B., Rossmark, B. M. M., \& van Hell, J. G. (2014). Parallel language activation during word processing in bilinguals: Evidence from word production in sentence context. Bilingualism: Language and Cognition, 17, 258276. http://dx.doi.org/10.1017/S1366728913000308

Śniatkowski, S. (2002). Milczenie i pauza w gramatyce nadawcy i odbiorcy. Ujęcie lingwoedukacyjne [Silence and pauses in the grammar of speakers and listeners. The educational linguistic perspective]. Kraków: Wydawnictwo Naukowe Akademii Pedagogicznej.

Tucker, G. R. (1998). A global perspective on mltilingualism and multilingualeducation. In J. Cenoz \& F. Genesee (eds.), Beyond bilinguals: Multilingualismand multilingual education (pp. 3-15). Clevedon, UK: Multilingual Matters.

Von Holzen, K., \& Mani, N. (2012). Language nonselective lexical access in bilingual toddlers. Journal of Experimental Child Psychology, 113, 569-586. https://doi.org/10.1016/j.jecp.2012.08.001

Wagner, A. (2017). Rytm w mowie i języku w ujęciu wielowymiarowym [Rhythm in speech and language in a multifaceted perspective]. Warsaw: Wydawnictwo Elipsa.

Werker, J. F., Byers-Heinlein, K., \& Fennell, C. T. (2009). Bilingual beginnings to learning words. Philosophical Transactions of the Royal Society of London B: Biological Sciences, 364, 3649-3663.

Wodniecka, Z., Mieszkowska, K., Duplik, J., \& Haman, E. (2018). Kiedy $1+1 \neq 2$, czyli jak dwujęzyczni przyswajają i przetwarzają język(i)? [When $1+1 \neq 2$ : how bilinguals acquire and process language(s)). In E. Czaplewska (ed.), Logopedia międzykulturowa [Intercultural logopaedics] (pp. 92-131). Gdańsk: Harmonia-Universalis.

Woźniak, T. (2012). Niepłynność mówienia [Non-fluency in speaking]. In S. Grabias \& M. Kurkowski (eds.), Logopedia. Teoria zaburzeń mowy [Non-fluency in speaking] (pp. 549-565). Lublin: Wydawnictwo UMCS.

Zurer-Pearson, B. (2013). Jak wychować dziecko dwujęzyczne [Raising a bilingual child]. Poznań: Media Rodzina. 